\title{
PENERAPAN LOGIKA FUZZY UNTUK PENGENDALIAN KUALITAS UDARA PADA RUANGAN SMOKING AREA DENGAN MIKROKONTROLER
}

\author{
Rommy Zohara Shoma, Sidik Noertjahjono, Joseph Dedy Irawan \\ Program Studi Teknik Informatika S1, Fakultas Teknologi Industri \\ Institut Teknologi Nasional Malang, Jalan Raya Karanglo km 2 Malang, Indonesia \\ Rzs10.rz@gmail.com
}

\begin{abstract}
ABSTRAK
Indonesia merupakan negara berkembang yang memilik konsumsi rokok yang cukup tinggi oleh penduduknya, sekitar kurang lebih $29 \%$ dari penduduk merupakan seorang perokok aktif. Berdasarkan fakta yang sudah disebutkan sebelumnya, maka cukup banyak asap yang akan bermunculan. Tak terlepas pada ruangan terbuka, smoking area sudah pasti akan menjadi tempat yang banyak mengandung asap rokok. Sebagai contoh perkembangan teknologi piranti piranti digital seperti mikrokontroler. Pemanfaatan mikrokontroler akan banyak membawa dampak pada kemudahan dan efektivitas kerja. Sebagai contoh rancang bangun sistem pengendalian kualitas udara pada smoking room akan sangat bermanfaat untuk memerbaiki kualitas udara pada suatu smoking room.

Studi ini mengajukan perancangan simulasi sistem kontrol suhu dan dan asap beserta implementasinya berupa prototype sistem pengendalian kualitas udara pada smoking room menggunakan mikrokontroller arduino. Sistem pengendalian kualitas udara pada smoking room ini dilengkapi dengan kemampuan pengatur kecepatan kipas yang sudah diprogram pada mikrokontroler berdasarkan kaidah logika fuzzy yang diterapkan.

Penelitian ini menghasilkan prototype sistem pengendalian kualitas udara pada smoking room yang dilengkapi dengan fitur informasi kondisi udara pada ruangan yang ditampilkan pada suatu web, Sistem ini bekerja dengan menggunakan beberapa perangkat keras diantaranya: Arduino, Sensor Suhu, Sensor asap, driver motor juga kipas
\end{abstract}

Kata kunci : suhu, asap rokok, fuzzy, web

\section{PENDAHULUAN}

\subsection{Latar Belakang}

Udara merupakan sesuatu yang sangat dibutuhkan oleh setiap makhluk hidup dalam kehidupan sehari hari baik untuk manusia ataupun hewan. Udara digunakan oleh manusia untuk bernafas, dan karnanya manusia sudah pasti membutuhkan udara yang bersih untuk bernafas. Udara yang bersih sudah pasti dibutuhkan semua orang, baik itu dewasa, lansia, atupun juga yang masih anak-anak.

Walaupun demikian cukup banyak orang yang mencemari udara bersih tersebut, contoh kecilnya dengan cara merokok di tempat umum. Tetapi hingga kini juga sudah terdapat area untuk merokok di tempat umum yang biasa desebut dengan smoking area. Smoking area pun juga ada yang bersifat ruang terbuka seperti di taman, juga pada ruang tertutup seperti di bandara, stasiun, mall, dan lain-lain. Menurut dr. Supriyatiningsih, Sp.OG, M.Kes, selaku Project Director Muhammadiyah Tobacco Control Center (MTCC) UMY dalam acara workshop KTR (Kampus Tanpa Rokok), ia memaparkan data dari Risekdas pada tahun 2017 menunjukan jumlah perok di Indonesia sebanyak $29.3 \%$ [1] yang artinya hampir 3 dari 10 orang Indonesia merupakan perokok.

Pada Smoking room biasanya memiliki ruangan yang sempit, minim ventilasi dan hampir benar benar tertutup. Kualitas udara pada kondisi seperti ini sudah pasti tidak baik untuk kesehatan utamanya pada pernafasan. Dengan kondisi ruangan yang tertutup atau minim ventilasi, maka asap yang dikeluarkan oleh para perokok yang ada di dalam area tersebut susah untuk keluar dan akan berkumpul di ruangan tersebut.

Dari penjelasan sebelumnya tercipta suatu pemikiran untuk mengimplementasikan sebuah logika fuzzy yang diterapkan pada suatu simulasi miniatur smoking room. Dimana sensor asap/gas berfungsi untuk merasakan banyak sedikitnya asap yang ada pada ruangan juga digunakan untuk mendeteksi bebarapa zat yang berbahaya pada rokok sepert aseton dan karbon monoksida dalam ruangan dan terdapat kipas mengarah ke luar ruangan untuk mengeluarakan asap yang dapat diatur kecepatan putarnya berdasarkan intensitas asap menggunakan logika fuzzy, juga sensor suhu untuk memonitoring suhu yang ada pada ruangan.

\section{TINJAUAN PUSTAKA}

\subsection{Penelitian Terkait}

Berdasarkan penilitian yang dilakukan oleh Emmalia Andriantantri dan Joseph Dedy Irawan pada tahun 2018, penelitit memaparkan bahwa perlunya monitoring serta pengontrolan untuk sebuah green house yakni sebuah rumah yang digunakan untuk memelihara tanaman tertentu. Pada peneleititan 
tersebut menunjukan keuntungan dari system monitoring yakni dapat dilakukakn secara jarak jauh dengan bantuan teknologi iot (Internet of Things).[2]

Kemudian pada tahun 2015, Ganjar Turesna dan kawan-kawan melakukan penelitian tentan bagai mana logika fuzzy dapat bermanfaat bagi manusia. Penelitian tersebut menerapkan logika fuzzy untuk menyelesaikan masalah tersbut dibantu dengan perangkat sensor seperti sensor cahaya yang dihubungkan ke sebuah mikrokontroler untuk diah datanya. [3]

Pada tahun 2019 Alfan Ahmad Afifudin juga melakukan penelitian tentang system monitoring yang menerapakan logika fuzzy. System tersebut melakukan monitoring pada kebutuhan air yang digunakan agar hemat dan tidak terlalu kencang jika saat isi dari tangki air tidak banyak. Sebaliknya air akan mengalir deras jika isi dari tangki air penuh. [4].

Di tahun 2019, Nouval Abdullah dkk melakukan sebuah penelitian bagiamana melakukan penyaringan zat dari asap rokok dengan menggunakan sensor gas seperti MQ-7. Penelitian yang dilakukan telah berhasil mengukur kadar minimum 0 PPM sampai maksimum sebesar 928 PPM dari pengukuran yang dilakukan oleh sensor MQ-7 lalu diberi set point pada 100 PPM untuk menggerakan sistem penyaringan kandungan karbon monoksida yang terdapat dalam asap rokok. [5]

\subsection{Logika Fuzzy}

Logika Fuzzy adalah metodologi sistem kontrol pemecahan masalah, yang cocok untuk diimplementasikan pada system mulai dari system yang sederhana, system kecil, system embedded. Jaringan PC, multichannel atau workstation berbasis akuisisi data dan system control. [6] berikut;

Urutan untuk algoritma fuzzy adalah sebagai

1. Fuzzifikasi, adalah proses yang dilakukan untuk mengubah variabel nyata menjadi variabel fuzzy.

2. Fuzzy Inferensi System, adalah proses penggabungan banyak aturan berdasarkan data yang tersedia. Sistem inferensi fuzzy merupakan suatu kerangka komputasi yang berdasarkan pada teori himpunan fuzzy, aturan fuzzy yang berbentuk IF-THEN, dan penalaran fuzzy.

3. Defuzzyfikasi adalah proses yang digunakan untuk mengubah kembali variabel fuzzy menjadi variabel nyata. Untuk proses defuzzifikasi menggunakan rumus sebagai berikut:

$\mathrm{z}=\frac{\text { apred }_{1} * \mathrm{z}_{1}+\text { apred }_{2} * \mathrm{z}_{2}+\ldots \ldots+\text { apred }_{n} * \mathrm{z}_{n}}{\text { apred }_{1}+\text { apred }_{2}+\ldots \ldots+\text { apred }_{n}}$

\subsection{Fuzzy Tsukamoto}

Fuzzy Tsukamoto merupakan salah satu metode dari Fuzzy Inference System. Dimana pada metode tsukamoto, setiap konsekuen pada aturan berbentuk if-then harus direprensetasikan dengan suatu himpunan fuzzy dengan fungsi keanggotaan yang monoton.

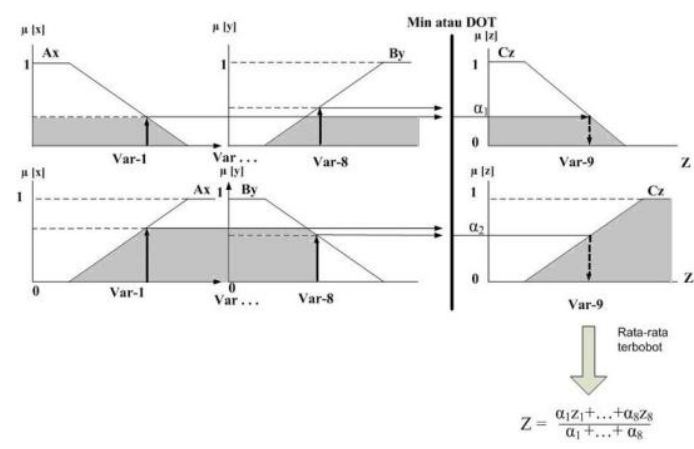

Gambar 2. 1 inferensi dengan menggunakan metode tsukamoto

\section{ANALISIS DAN PERANCANGAN SITEM \\ 3.1 Deskripsi Sistem dan Diagram Blok}

Sistem pengendali kualitas udara pada smoking room merupakan suatu system yang dapat mengontrol tingkat kepekatan asap yang ada pada suatu miniature smoking room dengan kipas yang terintegrasi dengan logika fuzzy sebagai penentu kecepatan putarnya.

Kebutuhan perangkat tersebut sesuai dengan blok diagram alat yang dibuat. Gambar blok diagram monitoring kualitas udara ditunjukkan pada Gambar 3.1

berikut.

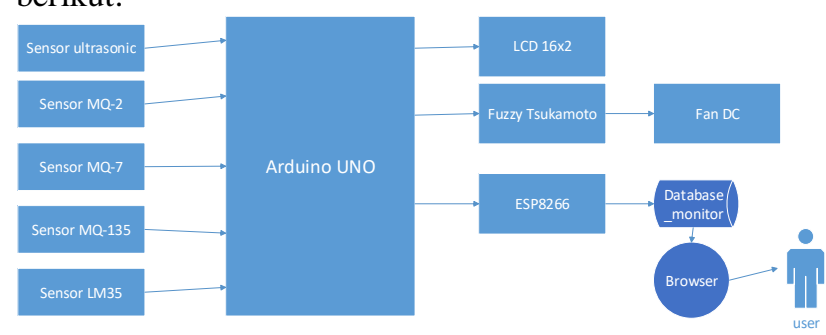

Gambar 3. 1 Diagram Blok Sistem pengendali kualitas udara

Adapun penjelasan dari diagram blok pada gambar 3. 1 Adalah sebagai berikut:

1. Yang pertama pembacaan seluruh sensor secara bersamaan mulai dari masing-masing sensor gas, sensor suhu, juga sensor ultrasoninc yang berperan sebagai pendeteksi adanya pengunjung yang masuk.

2. Kemudian nilai asap yang didapat oleh sensor MQ 2 dan nilai suhu yang didapat oleh sensor DHT11 diolah untuk didapatkan nilai kecepatan kipas berdasarkan aturan logika fuzzy yang digunakan.

3. Setelah seluruh data didapat dari seluruh sensor, seluruh data tersebu kemudian dikirim ke database dengan menggunakan modul wifi esp8266-01. 
4. Bersamaan itu juga arduino mengirim data yagn terbaca ke lcd.

5. Pada bagian web browser, web kemudian melakukan update kondisi terkini pada miniature ruangan berdasarakan data terbaru yang ada pada database.

\subsection{Diagram alir sistem}

Flowchart program system pada sistem pengendali kualitas udara berikut menggambarkan alur kerja sistem yang akan berjalan dimulai dari pembacaan nilai sensor-sensor sampai dimana web menampilkan data. Berikut alur program pada sistem :

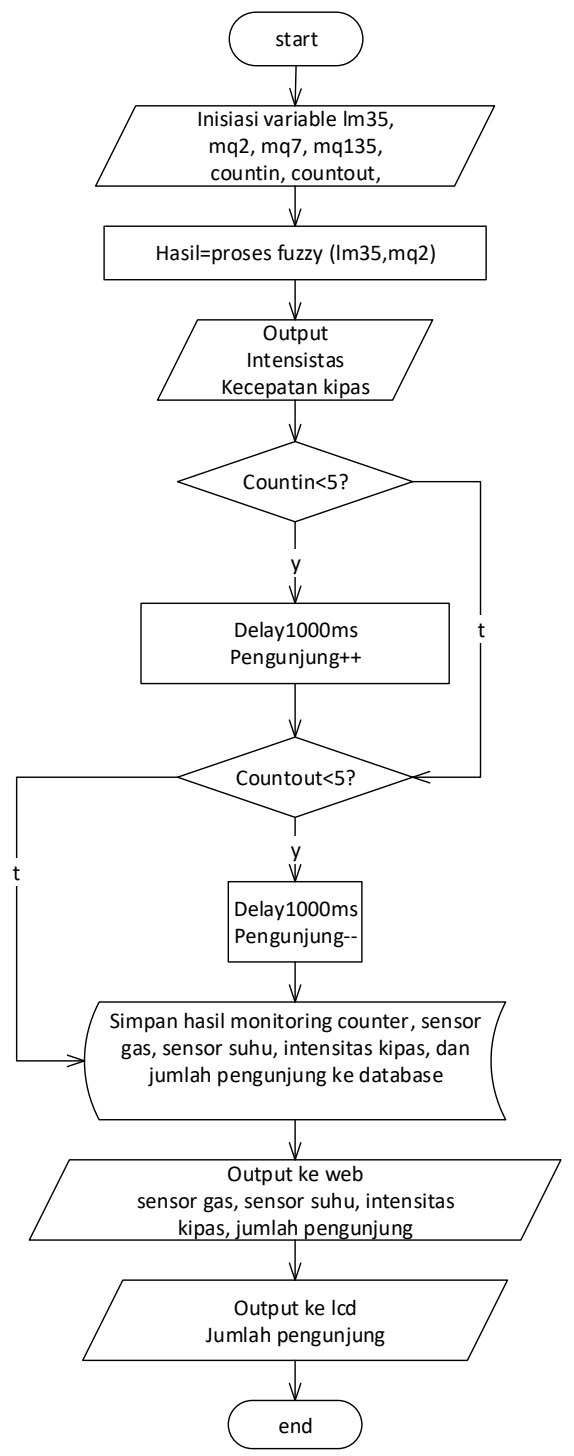

Gambar 3. 2 Flowchart Sistem

Pada flowchart di atas merupkan penjelesan dari keseluruhan alur system. Dimuali dari inisiasi sensor dan variable, kemudian hasil baca sensor suhu dan sensor asap diguanakan sebagai variable untuk penentuan kecepatan kipas menggunakan metode fuzzy.

\subsection{Skema Rangkaian Alat}

Alokasi pin adalah penempatan pin-pin yang terhubung satu sama lain pada minimum sistem Arduino Uno, adapun alokasi pin pada hardware yang dibutuhkan dapat dilihat pada gambar 3.2 berikut.

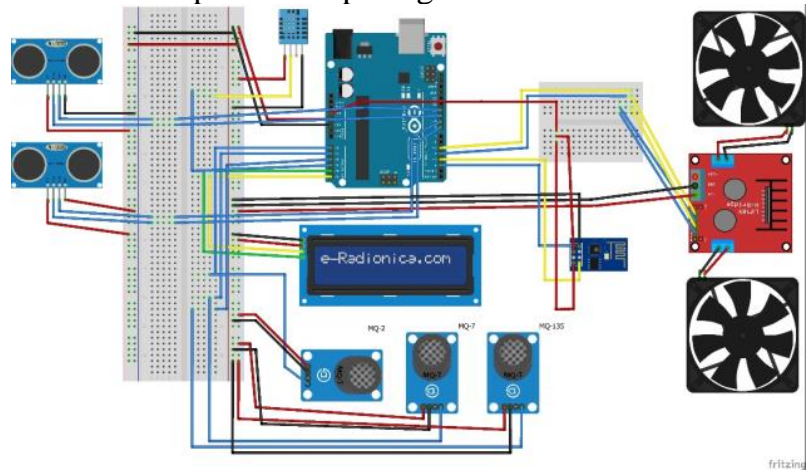

Gambar 3. 3 Skema Rancangan dan Alokasi pin

\subsection{Alur dan Penerapan Logika Fuzzy}

Alur kerja metode Logika Fuzzy yang diterapkan ditunjukkan pada Gambar 3.4 berikut.

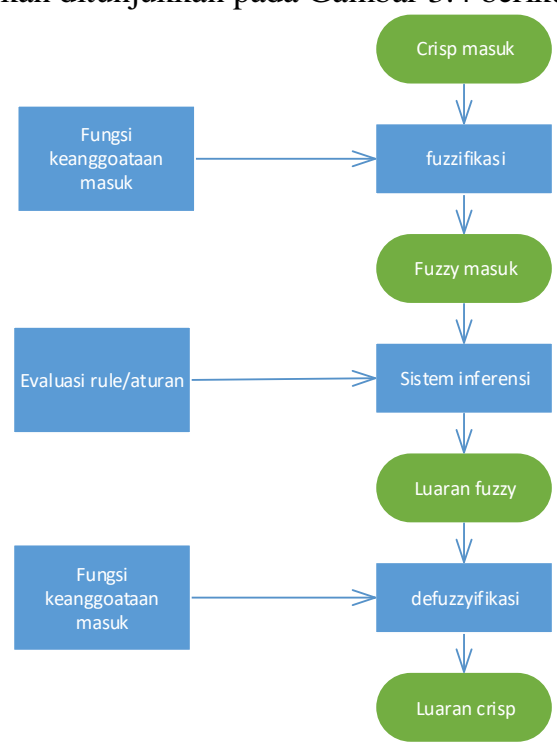

Gambar 3. 4 alur logika fuzzy

Penjelasan dari alur logika fuzzy diatas yakni

1. Fuzzifikasi mengubah masukkanmasukkan yang nilai kebenarannya bersifat pasti (crisp input) kedalam bentuk fuzzy input, yang berupa nilai linguistik yang ditentukan berdasarkan fungsi keanggotaan tertentu.

2. Inference melakukan penalaran menggunakan fuzzy input dan fuzzy rules yang telah ditentukan sehinggan menghasikan fuzzy output. 
3. Defuzzifikasi mengubah fuzzy output menjadi crisp value berdasarkan fungsi keanggotaan yang telah ditentukan.

\subsubsection{Penerapan Logika Fuzzy}

Penerapan logika fuzzy pada sistem pengendali kualitas udara adalah ada pada pengendali kecepatan putar kipas yang berfungsi untuk memasukan dan membuang udara dengan besaran bit sesuai dari hasil pembacaan sensor suhu dan sensor asap.

\subsubsection{Variabel dan Fungsi Keanggotaan}

Untuk menentukan kecepatan putar kipas(sebagai output), diperlukan kombinasi kriteria dari variabel input yang merupakan hasil baca suhu dari sensor DHT11 dan variable yang lain menggunakan hasil baca kepekatan asap dari sensor MQ 2. Deskripsi variabel serta fungi keangggotaan ada pada Tabel 3.3 berikut :

Tabel 3.1 Variabel dan fungsi keanggotaan

\begin{tabular}{|c|l|l|l|}
\hline Input & Output & \multicolumn{1}{|c|}{$\begin{array}{c}\text { Fungsi } \\
\text { keanggotaan }\end{array}$} & \multicolumn{1}{|c|}{ Nilai } \\
\hline \multirow{2}{*}{$\begin{array}{c}\text { Sensor } \\
\text { asap } \\
\text { MQ 2 }\end{array}$} & & Tidak ada & $0-5 p p m$ \\
\cline { 3 - 4 } & & Rendah & $3-13 p p m$ \\
\cline { 3 - 4 } $\begin{array}{c}\text { Sensor } \\
\text { suhu }\end{array}$ & Sedang & $10-20 \mathrm{ppm}$ \\
\cline { 3 - 4 } & & Tinggi & $18-25 \mathrm{ppm}$ \\
\cline { 3 - 4 } & & Rendah & $25-28^{\circ} \mathrm{C}$ \\
\cline { 3 - 4 } & & Sedang & $27-31^{\circ} \mathrm{C}$ \\
\cline { 3 - 4 } & Kipas & Tinggi & $30-33^{\circ} \mathrm{C}$ \\
\hline & & Lambat & $30-150 \mathrm{pwm}$ \\
\cline { 3 - 4 } & & Sedang & $130-200 \mathrm{pwm}$ \\
\cline { 3 - 4 } & & Cepat & $180-255 \mathrm{pwm}$ \\
\hline
\end{tabular}

Parameter diatas mengacu pada pada kepekatan yang dari asap yang terbaca oleh sensor MQ 2 juga besaran suhu yang dibaca oleh sensor suhu DHT11. Dari 2 para meter tersebut masing-masin terdapat dua keanggotaan yang digunakan sebagai acuan pembuatan aturan rule. Besaran yang diterima oleh kedua sensor tentunya akan mempengaruhi hasil defuzzifikasi untuk penentuan kecepatan putar kipas berdasarkan hasil inputan dari kedua sensor yang digunakan.

Gambar dibawah ini merupakan grafik fungsi keanggotaan sensor DHT11 dalam ruangan untuk membaca suhu seperti pada Gambar 3.5 berikut

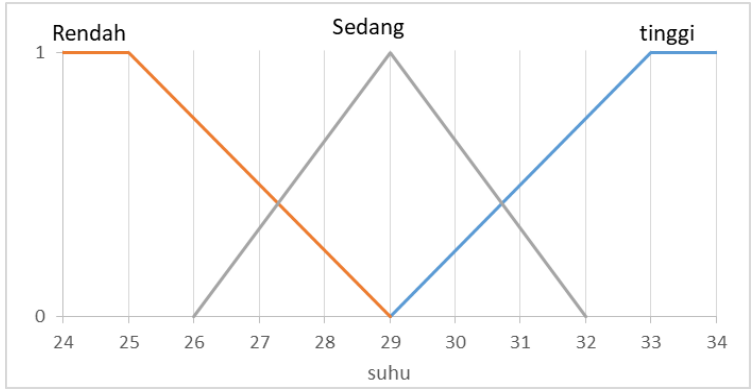

Gambar 3. 6 grafik keanggotaan input 1 (suhu).

Gambar diatas merupakan grafik keanggotan untuk nilai inputan dari sensor DHT11 dalam ruangan yang digunakan untuk melakukan pembacaan besaran suhu.

Gambar dibawah ini merupakan grafik fungsi keanggotaan sensor MQ 2 seperti pada Gambar 3.7 berikut :

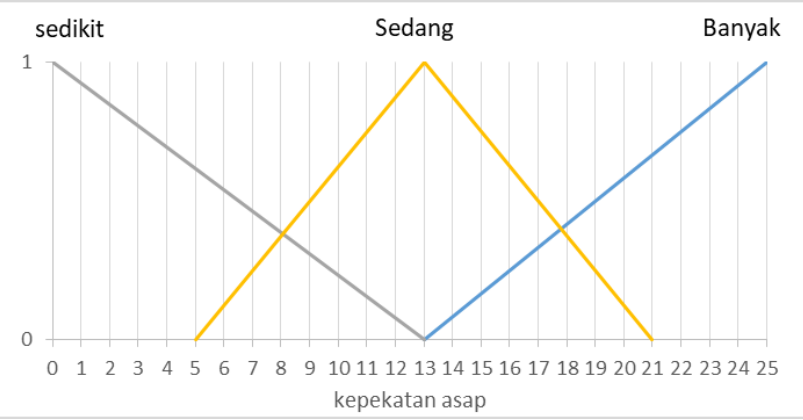

Gambar 3. 5 Grafik keanggotaan input 2 (kepekatan asap).

Gambar diatas merupakan grafik keanggotan untuk nilai inputan dari sensor MQ 2 yang membaca besara asap.

\subsubsection{Penalaran Rule Base}

Adapun penalaran rule base atau aturan dasar pada setiap variabel input dan output adalah pada Tabel 3.4 sebagai berikut :

Tabel 3.2 Penalaran Rule Base

\begin{tabular}{|l|l|}
\hline R1 & $\begin{array}{l}\text { IF suhu rendah AND asap sedikit } \\
\text { THEN kipas lambat }\end{array}$ \\
\hline R2 & $\begin{array}{l}\text { IF suhu rendah AND asap sedang } \\
\text { THEN kipas sedang }\end{array}$ \\
\hline R3 & $\begin{array}{l}\text { IF suhu rendah AND asap banyak } \\
\text { THEN kipas cepat }\end{array}$ \\
\hline R4 & $\begin{array}{l}\text { IF suhu sedang AND asap sedikit } \\
\text { THEN kipas sedang }\end{array}$ \\
\hline R5 & $\begin{array}{l}\text { IF suhu sedang AND asap sedang } \\
\text { THEN kipas sedang }\end{array}$ \\
\hline R6 & $\begin{array}{l}\text { IF suhu sedang AND asap banyak } \\
\text { THEN kipas cepat }\end{array}$ \\
\hline R7 & $\begin{array}{l}\text { IF suhu tinggi AND asap sedikit } \\
\text { THEN kipas cepat }\end{array}$ \\
\hline R8 & $\begin{array}{l}\text { IF suhu tinggi AND asap sedang } \\
\text { THEN kipas cepat }\end{array}$ \\
\hline R9 & IF suhu tinggi AND asap banyak \\
\hline
\end{tabular}




\section{THEN kipas cepat}

\section{IMPLEMENTASI DAN PENGUJIAN}

\subsection{Implementasi Sistem}

Berdasarkan hasil analisis dan perancangan pada Bab III. Diimplementasikan sistem penerapan logika fuzzy untuk pengendalian kualitas udara pada smoking room sebagai berikut :

\subsubsection{Hasil Implementasi Hardware}

Pada implementasi perangkat keras pengendali kualitas udara didapati bentuk rangkaian alat terlihat seperti pada Gambar.4.1

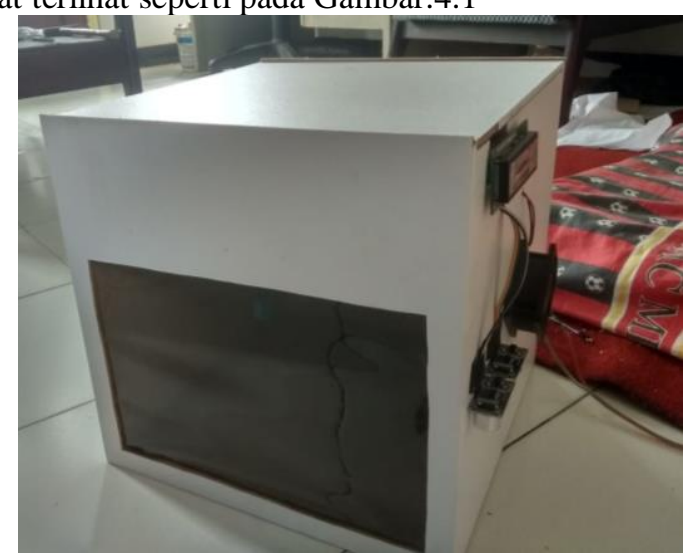

Gambar 4. 1 Implementasi Komponen

Model desain sistem pengendali udara yang dibuat sesuai dengan perancangan hardware. Pada Gambar 4.1 menunjukkan model desain hardware yang terdiri dari beberapa komponen dengan fungsi dan tugas masing - masing

\subsubsection{Hasil Implementasi Sofware}

1. Halaman utama web (home)

Pada halaman home merupakan dimana halaman utama untuk pengunjung seperti pada gambar 4.2 berikut

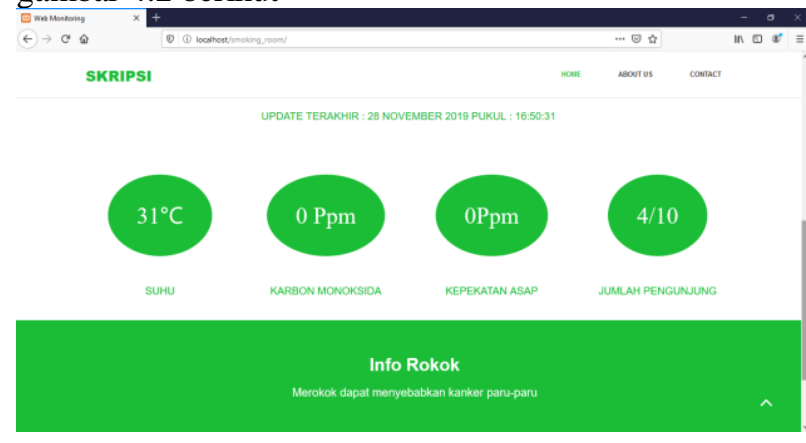

Gambar 4.2 Tampilan halaman User

\section{Halaman Login}

Halaman login seperti pada Gambar 4.3 digunakan untuk admin login ke menu informasi rokok.

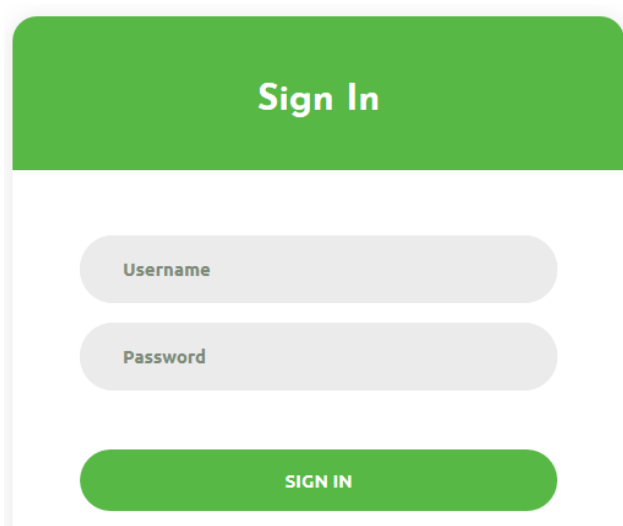

Gambar 4. 3 Halaman Login Admin

3. Halaman admin info rokok

Halaman yang berfungsi mengontrol menu info rokok yang ada pada halaman utama (home) seperti pada gambar 4.4 berikut.

\begin{tabular}{|c|c|c|c|c|}
\hline$\equiv$ & \multicolumn{3}{|c|}{ Tabel Informasi } & Log out \\
\hline & \multicolumn{2}{|c|}{ Info } & opsi & \\
\hline & \multicolumn{2}{|c|}{ Merokok dapat menyebabkan kanker paru-paru } & Hapus & \\
\hline & \multicolumn{2}{|c|}{$\begin{array}{l}\text { Kandungan bahan kimia yang bersifat beracun pada rokok dapat } \\
\text { mengurangi produksi sperma pada pria, juga dapat mengakibatkan } \\
\text { impotensi }\end{array}$} & Hapus & \\
\hline & \multicolumn{2}{|c|}{$\begin{array}{l}\text { Bahaya dari zat nikotin dapat menyebabkan kerusakan sel-sel } \\
\text { dalam organ paru-paru yang bisa berakibat fatal seperti munculnya } \\
\text { kanker paru-paru. }\end{array}$} & Hapus & \\
\hline & \multicolumn{2}{|c|}{$\begin{array}{l}\text { Bahaya merokok bagi kesehatan juga bisa dirasakan sampai ke } \\
\text { lambung, karena asap rokok yang masuk ke sistem pencernaan } \\
\text { akan menyebabkan meningkatnya asam lambung. Jika hal ini } \\
\text { dibiarkan terus menerus maka bukan tidak mungkin akan menjadi } \\
\text { penyakit yang lebih kronis seperti tukak lambung yang lebih sulit } \\
\text { diobati. }\end{array}$} & Hapus & \\
\hline & Tambah Data & Edit Informasi & & \\
\hline
\end{tabular}

Gambar 4. 4 halaman tabel info rokok (admin).

\subsection{Pengujian}

Setelah diimplementasikan, sistem pengendali kualitas udara dalam bentuk prototype akan dilakukan pengujian terhadap alat tersebut baik dari segi pengoperasian sensor ataupun komunikasi pengiriman data melalui internet.

\subsubsection{Pengujian Hardware}

\section{Pengujian sensor MQ 7}

Pengujian deteksi gas karbon monoksida dengan sensor MQ 7 dilakukan dengan cara membandingkan hasil output dari serial monitor arduino IDE dengan alat pendeteksi gas dan suhu CO UYIGAO UA506 dari asap hasil pembakaran kertas. Pembandingan dapat dilihat pada gambar 4.5 berikut 


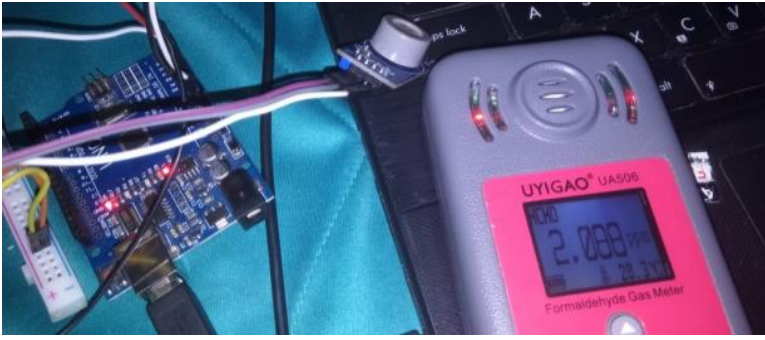

Gambar 4.5 hasil uji sensor MQ 7

Tabel 4.1 hasil pengujian sensor MQ 7

\begin{tabular}{|l|l|l|l|l|}
\hline \multirow{2}{*}{ No } & \multicolumn{2}{|c|}{ Hasil baca (ppm) } & \multirow{2}{*}{ selisih } & $\begin{array}{c}\text { Kesalahan } \\
(\%)\end{array}$ \\
\cline { 2 - 3 } & $\begin{array}{c}\text { Sensor MQ } \\
7\end{array}$ & UYIGAO & & \\
\hline 1 & 4.5 & 4.9 & 0.4 & 8.16326531 \\
\hline 2 & 2.9 & 2.4 & 0.5 & 20.8333333 \\
\hline 3 & 1.25 & 1 & 0.25 & 25 \\
\hline 4 & 4.9 & 5.2 & 0.3 & 5.76923077 \\
\hline 5 & 4.9 & 5.3 & 0.4 & 7.54716981 \\
\hline \multicolumn{2}{|l|}{ rata rata kesalahan } & 13.4625998 \\
\hline
\end{tabular}

Berdasarkan pengujian sensor MQ 7 pada Tabel 4.1 yang dilakukan sebanyak $5 x$ (5 kali), didapati sensor mampu membaca kadar karbon monoksida yang ada dengan presentase kesalahan rata rata sebesar $13.5 \%$ dengan pembacaan kadar menggunakan alat ukur UYIGAO UA506.

\section{Pengujian sensor DHT11}

Pengujian deteksi besar suhu dengan sensor DHT11 dilakukan dengan cara membandingkan hasil output sensor pada serial monitor arduino IDE dengan alat pendeteksi gas dan suhu UYIGAO UA506 pada suhu ruangan saat sensor dan alat pembanding digunakan sperti pada gambar 4.6 berikut.

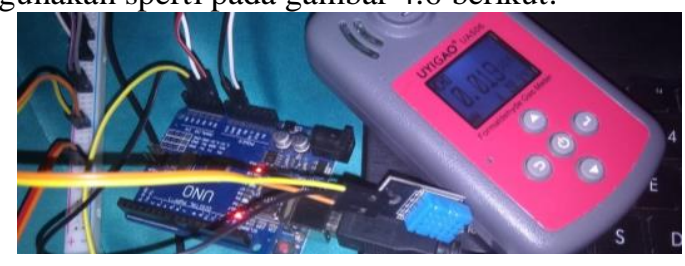

Gambar 4. 6 pengujian sensor suh DHT11

Tabel 4.2 hasil pengujian sensor DHT11

\begin{tabular}{|c|c|c|c|c|}
\hline \multirow[t]{2}{*}{ no } & \multicolumn{2}{|c|}{ Hasil baca (ppm) } & \multirow[b]{2}{*}{ selisih } & \multirow[b]{2}{*}{ Kesalahan (\%) } \\
\hline & $\begin{array}{l}\text { Sensor } \\
\text { DHT11 }\end{array}$ & UYIGAO & & \\
\hline 1 & 29 & 27.6 & 1.4 & 5.07246377 \\
\hline 2 & 29 & 28.6 & 0.4 & 1.3986014 \\
\hline 3 & 28 & 27.6 & 0.4 & 1.44927536 \\
\hline 4 & 29 & 29.8 & 0.8 & 2.68456376 \\
\hline 5 & 30 & 28.4 & 1.6 & 5.63380282 \\
\hline \multicolumn{4}{|c|}{ Rata rata kesalahan } & 3.24774142 \\
\hline
\end{tabular}

Berdasarkan pengujian sensor DHT11 pada

Tabel 4.2 yang dilakukan sebanyak $5 x$ (5 kali), didapati sensor mampu membaca kadar karbon monoksida yang ada dengan presentase kesalahan rata rata sebesar $3.2 \%$ dengan pembacaan suhu menggunakan alat ukur UYIGAO UA506.

3. Pengujian sensor ultrasonic

Pengujian sensor ultrasonic dilkaukan dengan meletakan penghalang pada bagian depan transmitter dan receiver sensor, bersamaan itu pula penggaris diletakan sejajar dengan arah dari transmitreceive sebagai alat ukur pembanding seperti pada gambar 4.5 berikut ini

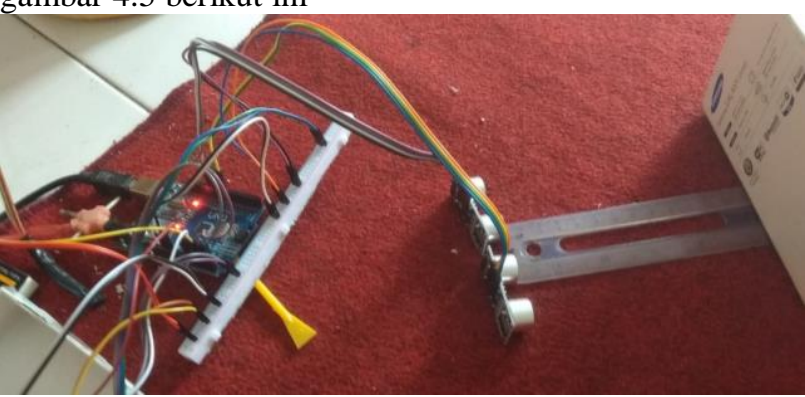

Gambar 4. 7 pengujian sensor ultrasonic

Tabel 4.3 hasil pengujian sensor ultrasonic

\begin{tabular}{|c|c|c|c|c|}
\hline \multirow[b]{2}{*}{ No } & \multicolumn{2}{|c|}{ Jarak penghalang } & \multirow[b]{2}{*}{ selisih } & \multirow{2}{*}{$\begin{array}{c}\text { Kesalahan } \\
(\%)\end{array}$} \\
\hline & $\begin{array}{l}\text { Sensor } \\
(\mathrm{cm})\end{array}$ & $\begin{array}{l}\text { Penggaris } \\
(\mathrm{cm})\end{array}$ & & \\
\hline 1 & 26 & 27 & 1 & 3.7 \\
\hline 2 & 13 & 13.3 & 0.3 & 2.2 \\
\hline 3 & 22 & 23 & 1 & 4.3 \\
\hline 4 & 6 & 7 & 1 & 14 \\
\hline 5 & 18 & 18.5 & 0.5 & 2.7 \\
\hline \multicolumn{4}{|c|}{ Rata rata kesalahan } & 5.38 \\
\hline
\end{tabular}

Berdasarkan pengujian sensor ultrasonic pada Tabel 4.3 yang dilakukan sebanyak 5x (5 kali) secara acak, bahwasannya sensor ultrasonic dapat bekerja dengan baik, meskipun masih terdapat nilai error pada data sensor. Rata rata yang didapat pada pengujian yang dilakukan menunjukan persentase eror pada sensor ultrasonic adalah sebesar 5.38

\section{Pengujian driver motor dan fan dc}

Untuk pengujian fan dc menggunakan driver motor 1298n sebagai pengatur kecepatan putaran dari kipas dengan menggunakan sinyal pwm yang dikirimkan oleh arduino, tegangan yang digunakan juga berada pada nilai $12 \mathrm{v}$.

Pengujian dilakukan dengan cara memberikan sinyal pwm pada driver yang sudah terhubung dengan kipas, kemudian kecepatan rpm diukur menggunakan sensor rpm (tacometer) seperti pada gambar 4.6 berikut. 


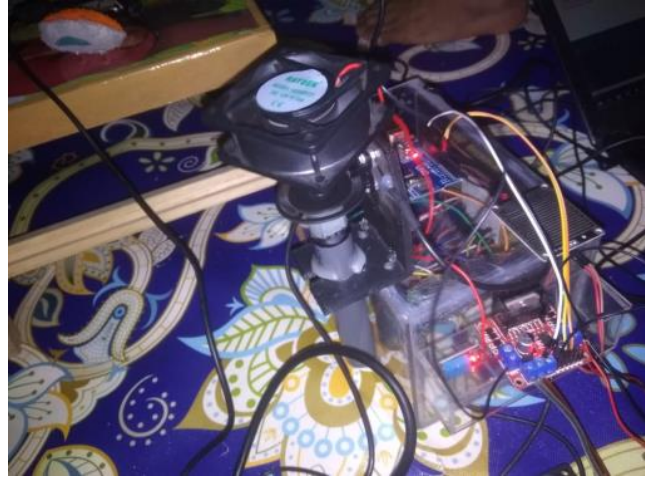

Gambar 4. 8 pengujian driver motor dan kipas dc

Hasil pengujian sinyal pwm dengan driver dapat dilihat pada tabel 4.4 berikut

Tabel 4.4 hasil pengujian driver motor dan fan dc

\begin{tabular}{|c|c|c|}
\hline NO & pwm & $\begin{array}{c}\text { Rotasi } \\
\text { permenit }\end{array}$ \\
\hline 1 & 60 & 649 \\
\hline 2 & 120 & 2076 \\
\hline 3 & 150 & 3336 \\
\hline 4 & 200 & 5827 \\
\hline
\end{tabular}

Berdasarkan tabel pengujian motor driver dan fan dc pada tabel 4.4, didapati jumlah putaran permenit bertambah semakin tinggi berdasarkan besar sinyal pwm yang diterima oleh driver dari arduino.

\section{Pengujian modul wifi esp 8266}

Pengujian pada modul ESP8266 atau disebut juga modul wifi ini diuji dengan cara melakukan pengiriman data pada sebuah suatu web server sebagai output dari hasil baca sensor. Untuk dapat beroperasi, modul wifi dihubungkan pada suatu jaringan internet local yang sama dengan webserver local berada. Alur dari pengujian modul wifi dapat dilihat pada gambar diagram 4.8 berikut

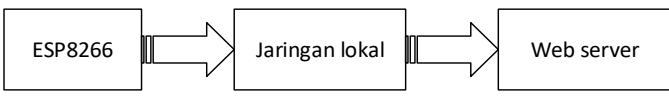

Gambar 4. 9 digram pengujian esp8266

Setelah modul wifi diprogram, modul wifi dapat melakukan pengiriman data ke webserver yang berada pada computer dengan syarat webserver dan modul wifi tersebut ada pada satu jaringan yang sama.

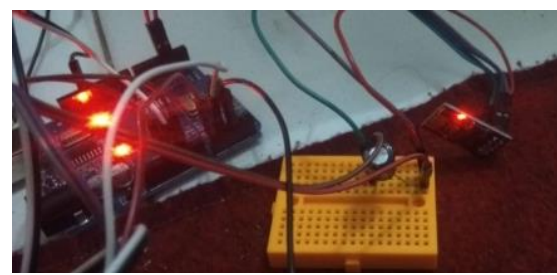

Gambar 4. 10 pengujian pengiriman data oleh modul wifi
Pengujian pada serial monitor arudino IDE

dapat dilihat pada gambar 4.11 berikut

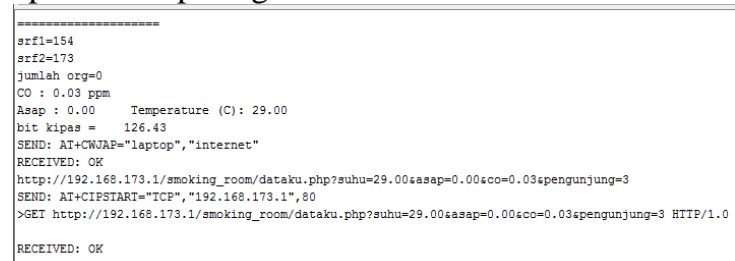

Gambar 4. 11 hasil serial monitor pengujian modul wifi

Pada gambar diatas pengujian meliputi dua langkah yakni yang pertama melakukan penghubungan ke jaringan ssid dengan perintah "SEND : AT+CWJAP='laptop','internet",, jika proses menghubungkan ke jaringan berhasil maka serial monitor akan menampilkan teks "RECEIVED $=O K$ " dan "RECEIVED $=E R R O R$ " bila gagal. Kemudian pada langkah berikutnya bila proses koneksi berhasil, modul wifi akan melakukan pengiriman data ke web server.

4. Pengujian Logika fuzzy

Pengujian logika fuzzy yang diterapkan pada sistem dilakukan dengan cara memberi nilai dari suhu yang berbeda dan juga besaran asap yang akan diolah oleh mikrokontroler dengan perhitungan manual (excel).

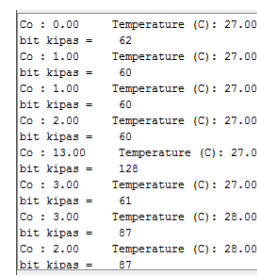

Gambar 4. 12 pengujian hasil fuzzy pada serial monitor

Tabel 4.5 hasil perbandingan logika fuzzy pada program dan sistem

\begin{tabular}{|c|c|c|c|c|c|c|c|c|}
\hline \multirow{3}{*}{ No } & \multicolumn{3}{|c|}{$\begin{array}{l}\text { Perhitungan } \\
\text { manual(excel) }\end{array}$} & \multicolumn{3}{|c|}{$\begin{array}{l}\text { Hasil fuzzy pada } \\
\text { sistem }\end{array}$} & \multirow{3}{*}{ 帝. } & \multirow{3}{*}{ 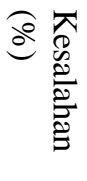 } \\
\hline & \multicolumn{2}{|c|}{ input } & \multirow{2}{*}{$\begin{array}{l}\text { output } \\
\text { pwm }\end{array}$} & \multicolumn{2}{|c|}{ input } & \multirow{2}{*}{$\begin{array}{l}\text { output } \\
\text { pwm }\end{array}$} & & \\
\hline & suhu & co & & suhu & co & & & \\
\hline 1 & 29 & 1 & 120 & 29 & 1 & 119 & 1 & 0.83 \\
\hline 2 & 29 & 2 & 116 & 29 & 2 & 115 & 1 & 0.86 \\
\hline 3 & 29 & 11 & 128 & 29 & 11 & 127 & 1 & 0.78 \\
\hline 4 & 29 & 14 & 142 & 29 & 14 & 142 & 0 & 0.00 \\
\hline 5 & 29 & 6 & 113 & 29 & 6 & 112 & 1 & 0.88 \\
\hline 6 & 29 & 15 & 144 & 29 & 15 & 143 & 1 & 0.69 \\
\hline 7 & 29 & 16 & 144 & 29 & 16 & 143 & 1 & 0.69 \\
\hline 8 & 29 & 4 & 112 & 29 & 4 & 111 & 1 & 0.89 \\
\hline 9 & 27 & 0 & 62 & 27 & 0 & 62 & 0 & 0.00 \\
\hline 10 & 27 & 1 & 60 & 27 & 1 & 60 & 0 & 0.00 \\
\hline 11 & 27 & 2 & 60 & 27 & 2 & 60 & 0 & 0.00 \\
\hline 12 & 27 & 13 & 128 & 27 & 13 & 128 & 0 & 0.00 \\
\hline 13 & 27 & 3 & 61 & 27 & 3 & 61 & 0 & 0.00 \\
\hline 14 & 28 & 3 & 87 & 28 & 3 & 87 & 0 & 0.00 \\
\hline
\end{tabular}




\begin{tabular}{|c|c|c|c|c|c|c|c|c|c|}
\hline \multirow{2}{*}{\multicolumn{2}{|c|}{\begin{tabular}{l|l}
15 & 28 \\
Rata-rata
\end{tabular}}} & 2 & 88 & 28 & 2 & 87 & 1 & 1.14 & \multirow{2}{*}{$\begin{array}{l}\text { dan Internet eplorer (11.0), khusus untuk bagian } \\
\text { ajax (refresh data) hanya mampu berjalan pada }\end{array}$} \\
\hline & & & & & & & & 0.45 & \\
\hline
\end{tabular}

fuzzy yang dibuat, rata-rata kesalahan yang yang muncul dari seluruh sampel yang ada pada tabel 4.5 adalah sebesar $0,45 \%$ yang artinya akurasi program logika fuzzy yang diterapak pada sistem adalah sebesar $99,55 \%$.

\subsubsection{Pengujian software}

Pengujian software pada penelitian ini dilakukan dengan melakukan pengujian kompabilitas website terhadap web browser seperti ditunjukan pada Tabel 4.6.

Tabel 4.6 pengujian web pada brwoser

\begin{tabular}{|l|l|c|c|c|}
\hline \multirow{2}{*}{ No } & \multicolumn{1}{|c|}{$\begin{array}{c}\text { Aspek } \\
\text { pengujian }\end{array}$} & $\begin{array}{c}\text { Mozila } \\
(70.0 .)\end{array}$ & $\begin{array}{c}\text { Microsoft } \\
\text { edge } \\
(20.10240)\end{array}$ & $\begin{array}{c}\text { Internet } \\
\text { eplorer } \\
(11.0)\end{array}$ \\
\hline 1 & $\begin{array}{l}\text { Halaman } \\
\text { home }\end{array}$ & $\checkmark$ & $\checkmark$ & $\checkmark$ \\
\hline 2 & $\begin{array}{l}\text { Halaman } \\
\text { login }\end{array}$ & $\checkmark$ & $\checkmark$ & $\checkmark$ \\
\hline 3 & $\begin{array}{l}\text { Halaman } \\
\text { tabel } \\
\text { informasi }\end{array}$ & $\checkmark$ & $\checkmark$ & $\checkmark$ \\
\hline 4 & $\begin{array}{l}\text { Aksi pada } \\
\text { halaman } \\
\text { tabel } \\
\text { informasi } \\
\text { tambah, } \\
\text { edit, hapus) }\end{array}$ & $\checkmark$ & $\checkmark$ & $\checkmark$ \\
\hline 5 & $\begin{array}{l}\text { Pembaruan } \\
\text { data tanpa } \\
\text { reload (ajax) }\end{array}$ & $\checkmark$ & $\times$ & $\times$ \\
\hline
\end{tabular}

\section{PENUTUP}

\subsection{Kesimpulan}

Dari beberapa tahapan pengujian dan perbandingan yang telah dilakukan terdapat beberapa kesimpulan, diantaranya :

Dari beberapa tahapan pengujian dan perbandingan yang telah dilakukan terdapat beberapa kesimpulan, diantaranya :

1. Logika fuzzy yang berjalan pada sistem memiliki kesalahan $0,45 \%$ dibandingkan dengan perhitungan manual (dengan excel) yang artinya program berjalan dengan akurasi sebsar 99,5\%.

2. Dengan menggunakan logika fuzzy maka kecepatan putar kipas dapat diatur sedemikian rupa sesuai dengan nilai input dari besaran sensor yang dibaca olesh sensor asap MQ 2 dan sensor suhu DHT11.

3. Dari hasil nilai sensor yang terdapat kesalahan pada sensor MQ-7 sebesar $13.5 \%$, dan sensor DHT11 sebesar $3.25 \%$ pada masing masing alat pembanding pada sensor yang digunakan.

4. Website dapat berjalan dengan baik pada browser Mozila (70.0.), Microsoft edge (20.10240)

\subsection{Saran}

Adapun beberapa saran yang dapat diberikan setelah melakukan pengembangan sistem dan beberapa pengujian, diantaranya :

1. Karena modul esp8266 membutuhkan delay untuk melakukan pengiriman data, maka modul tersebut dapat diganti dengan modul wifi yang lain yang setidaknya memiliki delay lebih sedikit agar data yang dikirimkan data berjalan secara realtime.

2. Untuk mengatasi masalah fan dc yang lemah saat mendapat sinyal pwm rendah dapat digunakan adaptor yang lebih baik sebagai sumber tenaga untuk driver motor.

3. Pengurangan delay pada modul wifi dapat mengakibatkan modul wifi menjadi cepat panas, dapat menggunakan modul real time clock untuk mengatur interval pengiriman agar modul wifi terdapat jeda pengiriman antar data.

\section{Daftar pustaka}

[1] Anonymous. 2012. Jumlah Perokok di Indonesia Masih Tinggi, http://www.umy.ac.id/jumlahperokok-di-indonesia-masih-tinggi.html (Senin 30 september $201910.58 \mathrm{pm}$ ).

[2] Adriantantri, E., \& Dedy Irawan, J. (2018). Implementasi IoT Pada Remote Monitoring Dan Controlling Green House. Jurnal Mnemonic, 1(1).

[3] Turesna, G., Zulkarnain, Z., \& Hermawan, H. (2017). Pengendali intensitas lampu ruangan berbasis Arduino UNO menggunakan metode fuzzy logic. Jurnal Otomasi Kontrol dan Instrumentasi, 7(2), 73.

[4] Afifuddin, A. A. (2019). PENERAPAN METODE FUZZY UNTUK MONITORING PENGGUNAAN AIR RUMAH TANGGA BERBASIS ARDUINO. Jurnal Mahasiswa Teknik Informatika, 3(1), 31-38.

[5] Abdullah, N., Suhendi, A., \& Suwandi, S. (2019). Perancangan Dan Implementasi Alat Penyaring Hidrogen, Metana Dan Karbon Monoksida Yang Terkandung Dalam Asap Rokok Berbasis Arduino Uno. eProceedings of Engineering, 6(1).

[6] Naba, Agus. 2009, Belajar Cepat Fuzzy Logic Menggunakan MATLAB, Yogyakarta, Andi Offset.

[7] ACHMAD SOLICHIN, 2010, MySQL 5 Dari Pemula Hingga "?Mahir, http://achmatim.net/2010/01/30/buku-gratismysql-5-dari-pemula-hingga-mahir, tanggal diakses 1 november 2019 . 